John Carroll University

Carroll Collected

2019

A Bridge Too Short: The Catholic Response to Racism and Segregation in Cleveland, Ohio in the 1960s.

James Gutowski

Follow this and additional works at: https://collected.jcu.edu/fac_bib_2019

Part of the Catholic Studies Commons 


\title{
A Bridge Too Short: The Catholic Response to Racism and Segregation in Cleveland, Ohio in the 1960s
}

\begin{abstract}
James A. Gutowski
Cleveland, Obio in the 1960s was a city divided by race. Prejudice and segregation led to animosity and violence. In 1967 the National Catholic Conference on Interracial Justice (NCCIJ) developed a pilot program, Project Bridge, that applied new ideas to old problems. Coming to Cleveland in 1968, the program generated new approaches for addressing racial justice, with mixed results. Ultimately, the same spirit of innovation that made Project Bridge possible later carried it into militancy and a premature demise.
\end{abstract}

Keywords: Cleveland, Ohio; race relations; National Catholic Conference on Interracial Justice; Project Bridge

\begin{abstract}
1 wo statistics from the 1960 census portended significant consequences for Cleveland, Ohio. First, the city's population dropped 4\% (from an all-time high of 914,000 in 1950), signaling the start of a
steep decline that continued for fifty years and drained over half of Cleveland's citizens. Second, while the city's overall population shrank, the number of African-Americans grew by almost $70 \%$ to make up nearly onethird of Cleveland's residents by $1960 .{ }^{1}$ Racial disparity developed as de facto segregation restricted blacks to neighborhoods often underserved by city services and public schools. Moreover, unethical real estate practices and decreasing home values fomented white flight and created resentment among the white citizens who remained. These factors led to both non-violent protests, as black parents sought better educational opportunities for
\end{abstract}

1. "Population of the 100 Largest Cities and Other Urban Places in the United States: 1790 to 1990," U.S. Census Bureau, https://www.census.gov/population/www/documentation/twps0027/twps0027.html. 
their children, and violent protests that in 1966 and 1968 required Ohio's National Guard to restore order.

For the Catholic Diocese of Cleveland, the 1960s presented a contrasting set of challenges. As the city was shrinking demographically, the Catholic population outside the city was growing dramatically. Within the city, however, the diocese faced urban challenges: shrinking populations in territorial and national parishes, incorporating black Catholics into predominantly European ethnic parishes, evangelizing new arrivals into the city, and, most importantly, developing an ecclesial identity among clergy and laity that transcended race. Still, the new reality presented fresh opportunities as the Church adapted to the changes brought by the Second Vatican Council (1962-1965) and focused on social concerns, including poverty and race.

Undoing decades of prejudice and resentment, however, proved to be a monumental task and the energy for change was ultimately found outside the Church. For a brief moment, however, this deepening crisis and the new opportunities attracted Project Bridge, an innovative program designed to apply the best practices of Catholic social justice and education in an ecumenical environment to address racism. Employing the principles of subsidiarity and collegiality to address the issue of race, the program manifested elements from the parable of the Sower and the Seed (Matthew 13:1-23; Mark 4:1-20; and Luke 8:4-15). As with the parable, the results were mixed at best until the ferment that made Project Bridge possible carried it beyond the Church's ability to support it.

\section{The Birth of Segregation in Cleveland}

Unlike the Jim Crow laws of the old Confederacy, segregation in Northern industrial states was less formalized and, therefore, more difficult to eradicate. The Great Migration quadrupled Cleveland's African-American population between 1910 and 1920, but a local custom permitted real estate transactions that forbade future property sales to African Americans. ${ }^{2}$ Although declared unconstitutional by the U.S. Supreme Court in 1917, the practice continued, leaving Cleveland's new arrivals restricted to Central Avenue. In some of the oldest housing in the city, Central Avenue white owners began charging higher rents and subdividing properties to house more tenants. ${ }^{3}$

2. Dorothy Ann Blatnica, VSC, "At the Altar of Their God": African American Catholics in Cleveland, 1922-1961 (New York: Garland Publishing, 1995), 15.

3. William W. Giffin, African-Americans and the Color Line in Ohio, 1915-1930 (Columbus: Ohio State University Press, 2005), 37-38. 
Many African Americans were drawn to Cleveland by the city's constant demand for unskilled factory labor, a factor that also pulled thousands of immigrants from Eastern and Southern Europe. Many immigrants settled into ethnic-specific neighborhoods so that by 1910 , almost $30 \%$ of the city's population was foreign-born, populating neighborhoods like Warszawa, Little Italy, and the Angle. ${ }^{4}$ The First World War and later immigration restrictions slowed European immigration considerably, creating more employment opportunities for African Americans from the South. ${ }^{5}$

As with other cities with large immigrant populations, Cleveland's ethnic Catholics put considerable effort into building parishes to serve their own nationalities. Czech Catholics established six parishes in the city, the Polish built more than a dozen, and additional ones were established by Germans, Hungarians, Slovenians, Italians, and Croatians. ${ }^{6}$ In 1960, 43 of Cleveland's 124 Catholic parishes served a particular ethnic group. ${ }^{7}$

The strong sense of national identity contributed to a pervasive sense of parochialism. John McGreevy wrote about the trend of ethnic Catholics in Northern cities to identify their neighborhood by their parish, such as Cleveland's Slovak Catholics self-identifying as being from St. Benedict's rather than from Woodland Hills. ${ }^{8}$ For many Catholics, the parish was more than just a place of worship. It was a social center and source of economic uplift, overseen by a priest who often served as an intermediary for parishioners who did not speak English. ${ }^{9}$ This strong attachment to, and identification with, place became problematic when neighborhood demographics changed.

When the United States entered the Second World War, Cleveland's many factories proved vital and created an almost endless demand for labor, increasing black migration from the South. Industrial jobs were perceived as "Negro jobs" (such as heavy physical work in foundries and chemical plants), while those involving machinery were reserved for white laborers. ${ }^{10}$ The

4. Blatnica, "At the Altar of Their God," 16; Edward M. Miggins, "The Ethnic Mosaic," in The Birth of Modern Cleveland 1865-1930, ed. by Thomas F. Campbell and Edward M. Miggins (Cleveland: Western Reserve Historical Society, 1988), 104-105.

5. Kenneth L. Kuzmer, A Ghetto Takes Shape: Black Cleveland, 1870-1930 (Urbana: University of Illinois Press, 1976), 164.

6. Miggins, "The Ethnic Mosaic," 113; John J. Grabowski, Polish Americans and their Communities of Cleveland (Cleveland: Cleveland State University, 1976), 254.

7. Official Catholic Directory (New York: P.J. Kenedy \& Sons, 1960), 361-363.

8. John T. McGreevy, Parish Boundaries: The Catholic Encounter with Race in the Twentieth-Century Urban North (Chicago: University of Chicago Press, 1996), 22.

9. Grabowski, Polish Americans and their Communities, 176.

10. Kimberley L. Phillips, AlabamaNorth: African-American Migrants, Community, and Working-Class Activism in Cleveland, 1915-1945 (Chicago: University of Illinois Press, 1999), 229. 
city's African-American population grew from 84,505 in 1940 to 147,847 in 1950, forcing the integration of neighborhoods adjacent to Central Avenue. ${ }^{11}$ In Surrogate Suburbs, Todd Michney identifies a pattern in which members of the black middle class, who had financial resources to pay higher rents and mortgages, settled in neighborhoods like Glenville and Mount Pleasant. They purchased homes from white families who were exercising their upward mobility by moving out to the newly-developing suburbs. Michney explains that many whites leaving these neighborhoods were Jewish and thus were more flexible about moving their cultural institutions, unlike their Catholic neighbors who remained emotionally attached to the parishes they had built. ${ }^{12}$

During the 1950s, the Hough neighborhood saw one of the city's most dramatic demographic turnovers. Populated in 1950 by 65,424 people in 23,118 houses (2.8 people per dwelling), in 1960 Hough contained 71,757 residents in 22,954 dwellings (3.1 per dwelling). ${ }^{13}$ Moreover, the non-white population rose from $5 \%$ to $74 \%$ in those same ten years. The increase in persons per dwelling occurred primarily through subdividing residences. ${ }^{14}$ "Blockbusting" was an equally controversial practice in which realtors terrified white householders with tales of plummeting property values to scare owners into selling their homes below market value. These were then sold to black homebuyers for a much higher price. ${ }^{15}$ Eventually outlawed, it undoubtedly added to tensions between white owners who refused to sell and newly-arriving black families.

Among the Catholic population, there were mixed reactions to the demographic change. In 1953, when auxiliary bishop Floyd Begin made a canonical visitation to St. Thomas Aquinas parish in the Hough, he reported that the pastor was panicked about the "Negro question" and requested a transfer "before the parish collapsed." 16 Begin himself was the pastor of another Hough parish: St. Agnes on Euclid Avenue, a magnificent Romanesque edifice built originally for upper-class Catholics, which was also transitioning into an African-American community. Unlike the pastor at St.

11. Blatnica, "At the Altar of Their God," 15.

12. Todd M. Michney, Surrogate Suburbs: Black Upward Mobility and Neighborhood Change in Cleveland, 1900-1980 (Chapel Hill: University of North Carolina Press, 2017), 55-56.

13. W. Dennis Keating and Norman Krumholz, eds., Rebuilding Urban Neighborhoods: Achievements, Opportunities and Limits (Thousand Oaks, CA: Sage Publications, 1999), 91.

14. Julian Chow, Shanta Pandey, and Claudia J. Coulton, Neighborhood Profile: A Profile of Social and Economic Conditions in the Hough Area (Cleveland: Center for Urban Poverty and Social Change, 1990), 51.

15. Michney, Surrogate Suburbs, 166.

16. Floyd Begin, "Notes," November 23, 1953, Archives of the Diocese of Cleveland, Cleveland, Ohio (hereafter ADC). 
Thomas, Bishop Begin embraced the new arrivals. ${ }^{17}$ In 1954, Begin clashed with Knights of Columbus Council 733 because they refused the application of three African Americans. That year's class of third-degree knights was named in Begin's honor, and he used the occasion of their acceptance ceremony to condemn the black applicants' rejection. Speaking to a crowd of 1,200 , the bishop denounced the refusal of a council charter to men from Central and Hough. ${ }^{18} \mathrm{He}$ attributed the rejection to race and announced that "anyone who denies that is a pussy-footing liar." 19 Begin continued advocating for his parishioners, regardless of race, until his appointment as bishop of Oakland, California, in 1963.

\section{Racial Tension and Violence}

By 1957, the de facto segregation of black citizens into specific neighborhoods created overcrowded conditions in segregated schools, prompting the Ohio State Board of Education to act. They approved a controversial "relay" program in which half of the school's students attended classes in the morning, and the other half attended in the afternoon. Parents at affected schools fought the relay program, forming the Hazeldell Parents Association (HPA), named after the school most affected by overcrowding. ${ }^{20}$

In 1962, after years of protest from the HPA, the Cleveland school district began bussing students from overcrowded schools to schools in all-white neighborhoods. However, contact between black and white students was minimized by requiring black students to remain in their classrooms with no access to the cafeteria, school nurse, or extracurricular activities. They were restricted to using the restroom only once per day at a designated time. ${ }^{21}$

When the school board refused to ease those restrictions, the HPA sought help from Cleveland's recently established civil rights organization, United Freedom Movement (UFM). After initial negotiations failed, the UFM wanted to raise public awareness and began demonstrating at the schools receiving the bussed students. On January 30, 1964, protestors traveled to the Little Italy neighborhood to picket Memorial Elementary School,

17. Encyclopedia of Cleveland History, s.v. "Floyd Begin," https://case.edu/ech/articles/b/begin-floyd-1.

18. "Bishop Begin Assails Five in Blocking of K of C Charter," Cleveland Plain Dealer, February 22, 1954, 4.

19. "Bishop Begin Weighs Switch to Interracial K of C Groups," Cleveland Plain Dealer, February 27, 1954, 9.

20. Leonard N. Moore, "The School Desegregation Crisis of Cleveland Ohio, 19631964," Journal of Urban History 28, no. 2 (January 2002), 136-137.

21. Ibid., 137-138. 


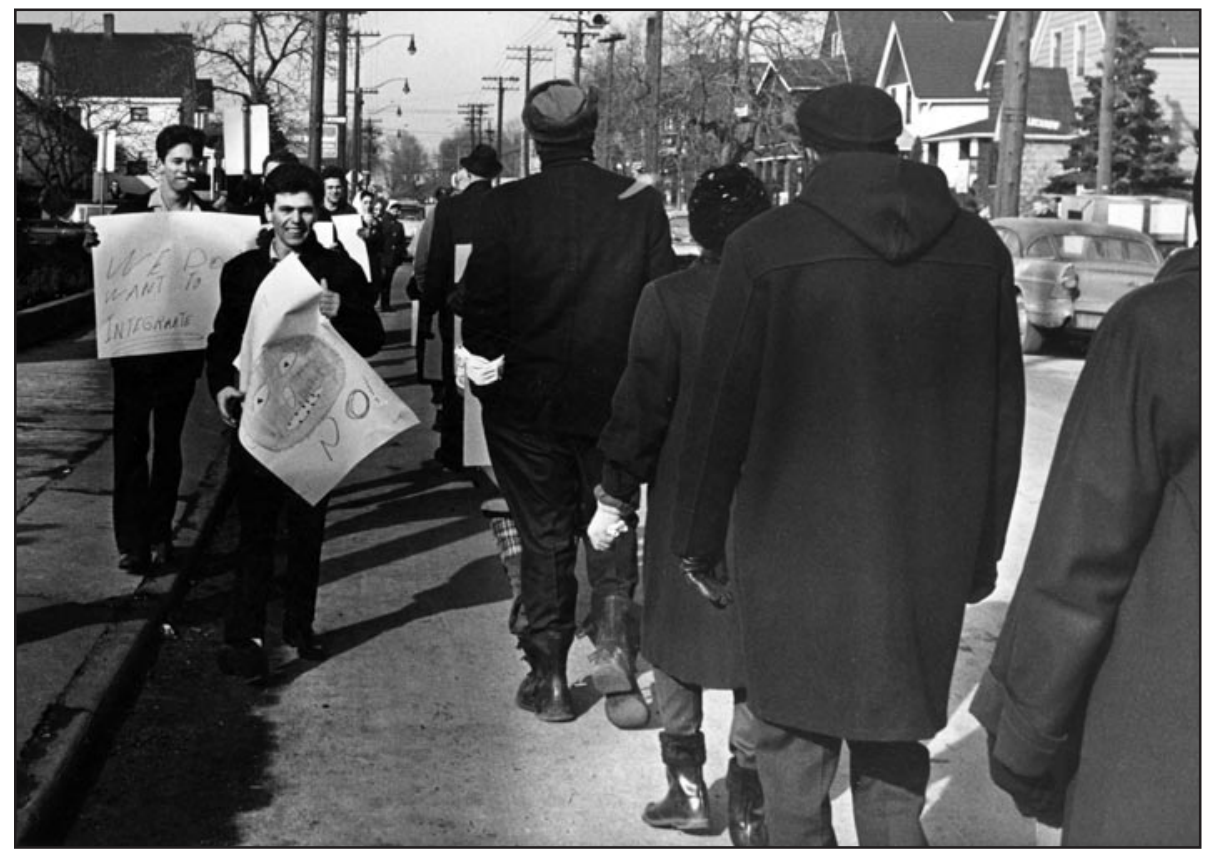

Residents of Little Italy greet African-American picketers hoping to integrate Memorial Elementary School, 1964 (Courtesy of Cleveland Memory Project).

but fighting broke out even before they arrived. A white mob numbering over 1,400 attacked black passers-by with bottles, bricks, and knives. ${ }^{22}$

Similar trouble on a smaller scale had erupted the previous day when the UFM picketed in the Collinwood neighborhood. Hoping to maintain peace, a dozen Catholic priests attended the Little Italy protest. Father Francis Gasbarre, pastor of Holy Rosary Church, an Italian parish one block from the school, scheduled a Holy Hour to begin at the same time as the protest, 9:30 am. He hoped to divert some counter-protestors from the school but less than fifty people joined him. Father James Miller, C.PP.S., an assistant pastor at another parish, tried to persuade the white crowd to go home, but his efforts were greeted with taunts: "Mind your own business, Father"; and "Pray for us; that's your job; pray for us." 23 The UFM returned to protesting the school board directly, but the violence in Little Italy was just a precursor of what would follow.

22. Ibid., 147.

23. James Flannery, "The Murray Hill Story-Thursday, January 30," [Diocese of Cleveland] Catholic Universe-Bulletin, February 7, 1964, 1. 
The city's growing racial tensions attracted the federal government's attention. In April 1966, the United States Commission on Civil Rights held hearings in Cleveland to receive testimony of ongoing segregation, discrimination, and racism. Convening on April 2, the Commission listened for six days as a procession of citizens shared stories of squalid living conditions, economic exploitation, police harassment, and civic neglect.

Father Vincent Haas, the pastor of the Conversion of St. Paul Shrine, was among those who testified. Present during the Little Italy demonstration on January 30, 1964, and moderator of the Catholic Interracial Council for Greater Cleveland, Father Haas testified about both that incident and the Church's response to racism. Father Theodore Hesburgh, C.S.C., President of the University of Notre Dame and a member of the Commission, asked Father Haas to explain how the local Church was addressing racism. Haas listed several diocesan initiatives, including the formation of interracial councils in Cleveland, Akron, and Lorain. In his assessment, the real obstacle to progress was the apathy shown by suburban Catholics who, though they worked in the city, remained blind to the tragedies of injustice around them. ${ }^{24}$

1966 became a pivotal and turbulent year for the city and Diocese of Cleveland. In failing health for years, Archbishop Edward F. Hoban died in September, and was succeeded by his coadjutor (an assistant with right of succession), the former bishop of Columbus, Clarence G. Issenmann. A month earlier the city was rocked by four days of fighting in the streets in what became known as the Hough riot. Amidst this, the local Church was undergoing ferment as decrees from the Second Vatican Council began transforming the liturgy, religious life, parish governance, and other facets of Catholic life. There were stormy days ahead.

On the evening of July 18, 1966, a black man entered the SeventyNiners Café at the corner of Hough Avenue and East 79th Street to ask for a cup of water. The bartender refused, pointing to the sign which read: "Colored not served here." A scuffle ensued and the police were called. The fight spread into the street and surrounding neighborhood. Police arriving on the scene called for reserves as the fight escalated into a riot. Fires were set and, when firefighters arrived, their hoses were cut and the firemen came under sniper fire. By morning, a dozen policemen had been wounded, thirty-eight fires set, and a young woman watching from an apartment window had been killed by a stray bullet. ${ }^{25}$

24. Hearing Before the United States Commission on Human Rights, April 1-7, 1966 (Washington, DC: Government Printing Office, 1966), 565-566.

25. Philip Porter, Cleveland: City on a Seesaw (Columbus: Ohio State University Press, 1976), 232. 
Fighting resumed the next night, prompting Mayor Ralph S. Locher to call in the Ohio National Guard, which arrived from Akron the next day, July 20. They cordoned off the troubled neighborhood and saw rioting that night, but on July 21 heavy rain discouraged further violence. An uneasy calm fell upon the city, but not before the riots had left four dead and thirty injured with nearly 300 arrests. ${ }^{26}$

The Diocese of Cleveland recognized the growing tensions and responded. Bishop Issenmann authorized interracial councils in Cleveland and nearby cities. He also established the Bishop's Committee on Urban Affairs (BCUA), a panel of seventy priests working in small committees to address urban issues, such as housing, employment, and immigration. ${ }^{27}$ In response to the riots, the diocese allocated $\$ 500,000$ to found the Better Homes for Cleveland Foundation (BHCF), tasked with rehabilitating 500 housing units in the Hough neighborhood. ${ }^{28}$ At Mayor Locher's request, Bishop Issenmann served on a commission investigating the causes of the riot, but he preferred to address race relations through diocesan efforts like the BCUA and BHCF. ${ }^{29}$

\section{Origins of Project Bridge}

The interracial councils of the Cleveland area were part of a larger movement begun in the 1930s, when Father John LaFarge, S.J., established the first Catholic Interracial Council in New York City. By 1960 the National Catholic Conference on Interracial Justice (NCCIJ) was established in Chicago to coordinate the efforts of Catholic interracial councils around the United States. The NCCIJ quickly became involved in the Civil Rights movement, recruiting over 900 Catholics to join Martin Luther King Jr.'s second march, from Selma to Montgomery, Alabama, on March 9, 1965. According to historian Amy Koehlinger, the media images of religious sisters in habits marching for civil rights sparked a growing trend among women's professed communities to more directly promote racial equality. ${ }^{30}$

In 1964, Mathew Ahmann, executive director of the NCCIJ, and Sister Claire Marie Sawyer, O.S.F., director of its Department of Education Services (DES), developed a traveling workshop on racial justice. Conducted by

26. Ibid.

27. Hearing Before the United States Commission on Human Rights, 566.

28. Bernard Meyer, ed., "Bishop Pledges \$500,000 Seed Money," Notice! News of the Inner City Environment (September 1967): 1, ADC.

29. "Bishop on Hough Committee," Cleveland Plain Dealer, August 3, 1966, 5; John F. Whealon to Thomas J. Gallagher, August 30, 1966, Issenmann Papers, ADC.

30. Amy L. Koehlinger, The New Nuns: Racial Justice and Religious Reform in the 1960s (Cambridge, MA: Harvard University Press, 2007), 51-54. 
teams of religious sisters during the summers when members were free from their regular teaching obligations, the workshops included a series of lectures supplemented by group discussions. Six workshops reached approximately 1,500 participants in the summer of 1965 . The next year those numbers jumped to forty-five workshops serving 14,000 attendees, and the program continued to expand throughout the decade. ${ }^{31}$

The traveling workshops' success sparked another idea: place a group of experts in an environment of racial tension to enable them to find ways to build connections among the racial, religious, and economic groups in the local community. ${ }^{32}$ This idea would become Project Bridge, an initiative of the NCCIJ in conjunction with the American Council for Nationalities Service (ACNS), a non-profit organization helping Eastern Europeans assimilate to life in the United States. Project Bridge's primary goal was to build better communication between African Americans and their ethnic neighbors. ${ }^{33}$ According to Roberta Steinbacher, a former Ursuline sister and founding member, Project Bridge was not designed for a specific city but conceived more generically to apply the best modern methods for building racial harmony at the grass-roots level. Collegiality and subsidiarity were foundational elements in the experiment. With a $\$ 200,000$ grant from the Ford Foundation, the project's planners sought a city that met two essential criteria: recent significant racial violence and a bishop who would welcome the project. After narrowing the choices down to Gary, Indiana and Cleveland, Ohio, the latter was ultimately selected. ${ }^{34}$ The diocese provided a home for the project in the former school for St. Marian Church, an Italian parish fourteen blocks from where the fighting had started in Hough.

The composition of its original staff exemplified the collegiality of Project Bridge. Bernard L. Friedberg, the executive director, had worked with the Anti-Defamation League of B'nai B'rith for the previous three years. Robert Carroll, assistant director, was an African American writer with experience in community relations. ${ }^{35}$ Five religious sisters comprised the "Human Relations University," the intellectual nucleus of the project. Each held a social science doctorate and would be responsible for a specific area of outreach. ${ }^{36}$ The five religious were Sister Esther Heffernan, O.P., a sociolo-

31. Ibid., 89-90.

32. Sister Helen Volkomener, F.C.S.P., "Project Bridge," The Providence Sister (Summer 1968), 3 .

33. Sister Loretto Anne Madden, S.L., "Project Bridge," Loretto Magazine (Summer $1968), 13$.

34. Roberta Steinbacher, interview with author, April 3, 2019

35. "Project Bridge Names Director," Cleveland Call and Post, December 2, 1967, 9A.

36. Ibid. 
gist from Madison, Wisconsin; Sister Mary Paul Norman, O.S.B., an historian from Crookston, Minnesota; Sister Roberta Steinbacher, O.S.U., a psychologist from Paola, Kansas; Sister Helen Volkomoner, F.C.S.P., an anthropologist from Seattle, Washington; and Sister Loretto Anne Madden, S.L., a sociologist from Denver, Colorado. ${ }^{37}$

Their primary goal was to collaborate with groups to transcend the boundaries of ethnic identities. ${ }^{38}$ Elements of subsidiarity were expressed in a pamphlet introducing Project Bridge to the community:

The training team will endeavor at all times to devise and initiate specific joint community projects involving the cooperation of different racial and nationality groups. These community projects will give people of different backgrounds an opportunity to work closely together to their own mutual advantage. . . . Central to Human Relations University's activities will be the bringing together of educational, clerical, business, professional, and political leaders in developing programs and techniques applicable to the needs and circumstances of Cleveland. Wherever possible the Team will utilize the resources of the city's existing organizations. ${ }^{39}$

The first quarterly report issued by Project Bridge revealed the broad scope of its outreach. The project had obtained funding for a program designed to foster good relations between two private and two public high schools. It was also working with a local organization, Plan for Action by Citizens in Education, to provide diverse learning experiences for city students through a summer program. Adult education was also addressed. Originally initiated by the Bishop's Committee on Urban Affairs, Project Bridge adopted a pulpit exchange program wherein a team of traveling priests preached on racial and social justice, targeting urban, ethnic parishes and parishes in the suburbs. Additionally, at St. John's College, a diocesansponsored school for teachers, the team of sisters offered an interdisciplinary course called "Man in Urban Society" to engender cultural sensitivity for teaching in mixed neighborhoods. ${ }^{40}$

One of Project Bridge's initial efforts proved to be its most enduring contribution to the city. Between 1955 and 1965, many urban parochial schools lost half of their enrollments. ${ }^{41}$ Three west side parishes, St. Wendelin, St.

37. Madden, "Project Bridge," 13 .

38. What is Project Bridge?, printed handout, 1-2, Roberta Steinbacher Papers (hereafter RSP), in possession of author.

39. What is Project Bridge?, 2.

40. An Interim Report on Project Bridge Covering the Period November 1, 1967 through January 31, 1968, 2-4, ADC.

41. Report, Bishop's Committee on Urban Affairs, 7-8, ADC. 


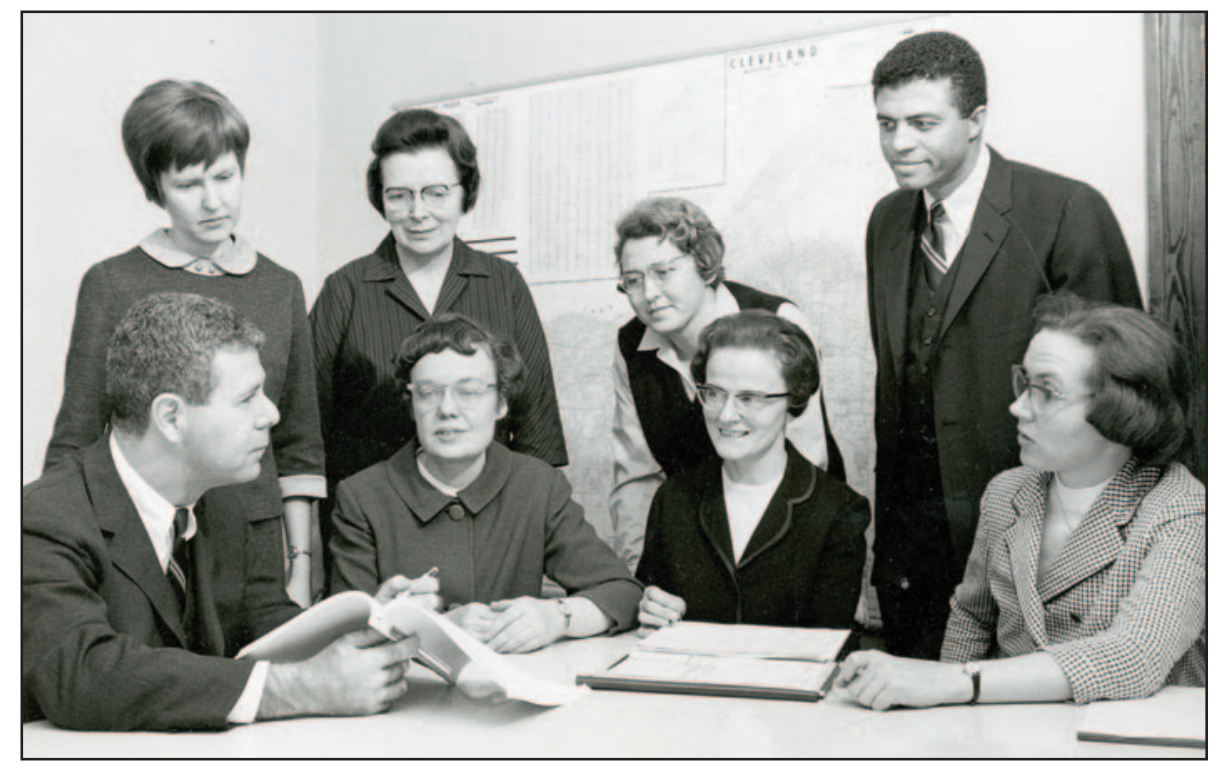

Project Bridge staff members Bernard Friedberg and Robert Carroll confer with the sisters comprising the Human Relations University (Courtesy of the Loretto Heritage Center and Archives, Nerinx, Kentucky).

Patrick, and St. Malachi, faced shrinking resources and deteriorating facilities. The latter two schools were staffed by Ursuline sisters, while St. Wendelin, a Slovak national parish, was served by Sisters of Notre Dame. Sister Helen Volkomener, F.C.S.P., suggested that the three schools combine resources to create a non-denominational entity administered by a lay board of directors. The pastor of St. Wendelin withdrew his school from the process, but the Catholic Board of Education approved the amalgamation of St. Patrick and St. Malachi schools to form the Urban Community School under the direction of the Ursuline sisters. The student body included members of the local black, Puerto Rican, and Appalachian communities as well as families who had been in the neighborhood for generations. ${ }^{42}$ Project Bridge underwrote the cost of a grant proposal that was eventually subsidized by a Cleveland couple for the first two years of the school's operation. ${ }^{43}$

Project Bridge also assisted in community organizing efforts. In the Collinwood and Hough neighborhoods, the sisters integrated with existing grassroots organizations to spur on projects for community improvement. The city-sponsored Cleveland Community Relations Board invited the sis-

42. Ibid., 9-11.

43. Barbara Ann Pleischl, "Urban Community School,” Momentum, April 1971, 27-28. 


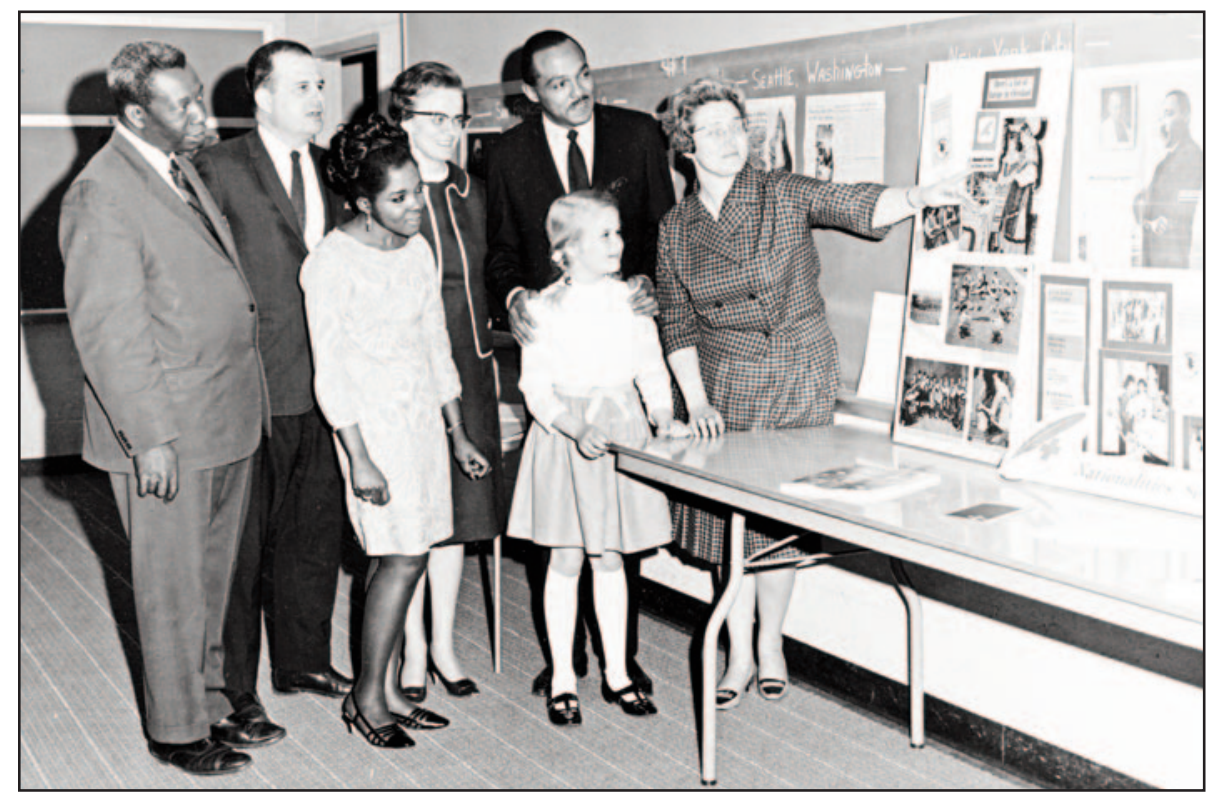

Cleveland Mayor Carl Stokes (second from right) and Len Zaller (second from left) admire a display at Project Bridge's headquarters (Courtesy of Providence Archives, Seattle, Washington).

ters to develop a community relations program in the Buckeye neighborhood, where the predominantly Hungarian population was altered by an influx of African-American families. The neighboring city of Parma was targeted for outreach during the summer of $1968 .^{44}$

Developing a media presence, Project Bridge sponsored radio shows on WZAK-FM, a station which programmed for ethnic audiences, and on WERE, with a show hosted by Pete Franklin (later a national sports talk show host). ${ }^{45}$ The local NBC affiliate even featured the project in a public affairs program. Project Bridge regularly advertised in the city's English-language papers and also five foreign-language papers. ${ }^{46}$ To encourage walk-ins, they opened the ground floor of their building at 2206 Petrarca Avenue as a public space for meetings, art exhibits, musical performances, and simple conversation. ${ }^{47}$ Eventually, the Afro-American Cultural and Historical Soci-

44. Ibid, 5 .

45. "WERE starts new intergroup show," [Diocese of Cleveland] Catholic Universe-Bulletin, January 19, 1968, 16.

46. Interim Report, 6-7.

47. "Bridge Dedicates New Communication Center," Cleveland Call and Post, May 11, $1968,11 B$. 
ety accepted an invitation to move its collection of artifacts to that space for public viewing. ${ }^{48}$

The success of the NCCIJ's traveling workshops encouraged Sister Margaret Traxler, S.S.N.D., who had succeeded Sister Claire Marie Sawyer as director of the NCCIJ's Department of Education Services (DES). She developed additional opportunities for teaching sisters to use their summer months promoting racial justice through programs like summer day camps in inner cities. President Johnson's war on poverty provided new funds for educational initiatives, including Head Start, which helped young children from lowincome families prepare to start school, and Upward Bound, which found college opportunities for high school students from that same demographic. In 1967 the DES inaugurated Cooperative Help of Integrated College Education (CHOICE) in which sisters taught at historically black colleges throughout the South, freeing faculty in the summer for research and writing. In 1968 a new option was added: Summer in Suburbia, a Project Bridge program coordinated by Sister Roberta Steinbacher, O.S.U., in which sisters went door-to-door in the Cleveland suburbs to engage people in conversations about racial justice. ${ }^{49}$

\section{Summer in Suburbia}

Summer in Suburbia (SIS) significantly shifted focus away from Project Bridge's initial intent to build connections between black and ethnic city residents. A report to the Ford Foundation listed the reasons for this shift, including strong resistance from city ethnics. The conclusions of the National Advisory Commission on Civil Disorder (also known as the Kerner Commission) highlighted for Bernard Friedberg and Sister Roberta the importance of engaging the white population outside the city. Recognizing the political and economic power of the suburbs, Steinbacher and Friedberg hoped to alert that demographic to the urgency of the situation and move them to positive action. ${ }^{50}$

Building on Sister Margaret's efforts, Project Bridge requested sisters from every women's religious community in the Midwest. Funding was scarce, but local donors contributed $\$ 8,000$, and the sending communities paid for the sisters' travel expenses to and from Cleveland. ${ }^{51}$ Participants

48. "Afro-American Society Moves to New Location," Cleveland Call and Post, April 20, $1968,3 \mathrm{~A}$.

49. Koehlinger, The New Nuns, 106-107.

50. Project Bridge: An Assessment of a Program to Improve Black-White Relations in Cleveland, Ohio, Project Evaluation by the Ford Foundation, August, 1969, 14-15, ADC.

51. Project Bridge: An Assessment of a Program to Improve Black-White Relations in Cleveland, Obio, 16. 
stayed in local convents, while the sisters of the Human Relations University received permission from their respective communities to subsidize SIS with their own paychecks. ${ }^{52}$

In June 1968, seventy-three sisters from forty-two different teaching communities arrived in Cleveland for five days of training before heading out to the suburbs in teams. ${ }^{53}$ The cities targeted were near the southern and western portions of Cleveland, including Berea, Brecksville, Broadview Heights, Fairview Park, Garfield Heights, Lakewood, Maple Heights, Parma, Parma Heights and Seven Hills, all areas with large Catholic populations. ${ }^{54}$

Knocking on 30,811 suburban doors, they began surveys by asking individuals to prioritize a list of values, hopefully setting the stage for further conversation about race and injustice. ${ }^{55}$ People giving high marks to freedom and equality would be identified as potential leaders for follow-up programs and invited to organizational meetings. However, the sisters quickly found that the format did not promote useful dialogue and discarded the survey in favor of more open-ended questions about race and civil disturbance. ${ }^{56}$

Unfortunately, most sisters of SIS found their assigned neighborhoods to be thorny ground at best. Of the almost 31,000 houses visited, only about half opened their doors to the visitors, with another 3,300 houses appearing to have someone at home who refused to answer the door. Many who did answer were either apathetic or grew openly hostile when prompted to discuss race. Some who were open-minded were afraid of their neighbors' reactions if they were seen promoting racial justice. Those already active in civil rights activities sometimes reported being harassed by their neighbors. ${ }^{57}$ In one spectacularly unfortunate incident, a white boy turned a garden hose on Sister Melanie Willingham, S.N.D. de N., an African-American sister working with a team of white sisters. ${ }^{58}$ Russell Faust, a journalist with the Catholic Universe-Bulletin was moved to write a column titled "Prejudice Heights" in which he described the depths of prejudice faced by Sister Melanie and her team. Of the six sisters, one aban-

52. Roberta Steinbacher, in discussion with the author, May 2019.

53. Project Bridge: An Assessment of a Program to Improve Black-White Relations in Cleveland, Obio, 16.

54. "Reactions vary for Sisters in suburbs," [Diocese of Cleveland] Catholic UniverseBulletin, June 28, 1968, 9.

55. Koehlinger, The New Nuns, 110-111.

56. Project Bridge: An Assessment of a Program to Improve Black-White Relations in Cleveland, Obio, 16-17.

57. Ibid., 17 .

58. Shannen Dee Williams, "Black Nuns and the Struggle to Desegregate Catholic America after World War I” (Ph.D. dissertation, Rutgers University, 2013), 202. 
doned SIS altogether and returned home while two others were permitted to move to different suburban teams. ${ }^{59}$

SIS also lacked support from diocesan priests, such that in August 1968, Project Bridge coordinators complained about the apathy of the Cleveland clergy. ${ }^{60}$ At least two pastors in Maple Heights reportedly complained that no one requested permission to work in their respective parishes. The sisters pointed out that such permission was unnecessary because they were contacting all people in Maple Heights, not just Catholics. One pastor grumbled that the sisters were using their habits as propaganda and should have stayed in their convents preparing their school work since they knew nothing of real estate or how "Negros depreciated property values."61

Despite the negative reactions and lack of institutional support, there were some positive outcomes. Organizational meetings were held in each community, involving those who had responded positively to their visit. Although most of these action groups faded quickly, at least three were still meeting a year later. ${ }^{62}$ The experience thoroughly energized some sisters, one writing to Sister Margaret Traxler thanking her for "one of the most worth-while and enriching experiences of my life." Encouraged by such reactions, the DES planned similar experiences for 1969 in Memphis and Baltimore. SIS was not repeated in Cleveland, but Project Bridge advised and supported the two new initiatives. ${ }^{63}$

While SIS was playing out in the suburbs, important changes were coming to Project Bridge. Cooperation between the two national organizations sponsoring Project Bridge broke down. Although the NCCIJ and ACNS jointly filed the request for continued funding, Mathew Ahmann of the NCCIJ began lobbying the Ford Foundation to assign sponsorship solely to his organization. Shortly after, Ahmann left the NCCIJ, and the Ford Foundation pressed Project Bridge to develop more local funding and sponsorship. ${ }^{64}$

In February 1968, Project Bridge had organized a thirty-nine-member advisory board headed by Len Zaller, a local businessman long active in

59. Russel Faust, "Prejudice Heights," [Diocese of Cleveland] Catholic Universe-Bulletin, July 26, 1968, 9 .

60. "'Suburbia' program ending," [Diocese of Cleveland] Catholic Universe-Bulletin, August 9, 1968, 10.

61. Sister Ruth, R.S.M., typed notes, July 11, 1968, RSP.

62. Project Bridge: An Assessment of a Program to Improve Black-White Relations in Cleveland, Ohio, 18.

63. Koehlinger, The New Nuns, 111.

64. Project Bridge: An Assessment of a Program to Improve Black-White Relations in Cleveland, Ohio, 18-19. 
Catholic social services. Born to Slovenian parents, Zaller was a founding member of the Cleveland branch of the Catholic Interracial Council. ${ }^{65}$ In many ways, he personified the demographic that Project Bridge was trying to reach. Tension, however, developed quickly between Zaller and Bernard Friedberg because the former felt that the executive director would not let the advisory board play a significant role in Project Bridge. As a step toward local sponsorship, the advisory board was converted to a board of directors, again chaired by Zaller. ${ }^{66}$

Project Bridge's second year brought a significant change in staffing. In August 1969, Friedberg resigned and was replaced by Thornton Webster, an African-American Clevelander who had been working for the Congress of Racial Equality. ${ }^{67}$ Four of the Human Relations University sisters returned to their respective communities, having been granted only a one year release for the project. Sister Roberta Steinbacher, O.S.U., however, remained and became assistant director. Along with these changes, the Ford Foundation approved a second year of funding with a larger grant of $\$ 225,000 .^{68}$

Sadly, the summer of 1968 also brought a new outbreak of racial violence, this time in Cleveland's east side Glenville neighborhood. On the evening of July 22, a gunfight broke out between police and the Black Nationalists of New Libya, a local militant group. Three policemen, three militants, and one civilian died, spawning four days of rioting. Elected as Cleveland's mayor a year earlier, Carl Stokes, the first black mayor of a major American city, tried to defuse some of the racial element in the fighting by ordering that only black police officers and community activists be allowed in the riot zone. Despite this, the violence escalated until the Ohio National Guard again restored order. ${ }^{69}$ Working in Cleveland's southern and western suburbs, the sisters of SIS escaped direct contact with the violence, but its proximity and the media attention could only have complicated their efforts to promote racial reconciliation.

Despite results that were mixed at best, SIS was among the more successful initiatives of Project Bridge's first year. Planned expansions to its pulpit exchange program for the second year were rejected by the Bishop's

65. "Leonard F. Zaller, worldwide marketer," Cleveland Plain Dealer, June 9, 1990, 26.

66. Project Bridge: An Assessment of a Program to Improve Black-White Relations in Cleveland, Obio, 18.

67. Ibid., 18.

68. “\$225,000 Granted to Project Bridge," Cleveland Plain Dealer, October 18, 1968,34 .

69. Lorraine Boissoneault, "What Happened When Violence Broke Out on Cleveland's East Side 50 Years Ago?," https://www.smithsonianmag.com/history/complicated-history1968-glenville-shootout-180969734/. 
Committee on Urban Affairs on "procedural grounds." A Ford Foundation report speculated that the involved priests preached ideas that were "too radical" for most parishes. ${ }^{70}$ Radio program sponsorship discontinued after a year because Webster did not observe a sufficient response from the listening public. Lastly, the public-private school cooperation was abandoned because one public and one Catholic school withdrew from the program citing too few results for the effort expended. ${ }^{71}$

\section{The Second Year of Project Bridge}

In its second year Project Bridge continued to shift its focus from ethnic groups to work in the suburbs. SIS produced three viable groups in Brecksville, Parma, and Lakewood, which continued meeting through the fall of 1968 before merging with other similarly-focused groups. ${ }^{72}$ Using lessons learned, Project Bridge established the Suburban Human Relations Foundation, led by Marlene Stoiber, to train small group leaders in recruitment, education, and action leadership. Working from home, each leader invited friends and neighbors to participate in a set of four weekly meetings. The first meetings educated the attendees on racial issues so that groups could later choose a particular focus and develop an action plan to work to improve that area. By June 1969 thirty groups were operating in western, southern, and eastern suburbs around Cleveland. ${ }^{73}$ Along with this success, the transition to local sponsorship occurred through funding from the George Gund Foundation, a local charity dedicated to human welfare. ${ }^{74}$

A spirit of militancy began to emerge in Project Bridge's second year, alienating many in the Church. In December 1968, Ebony published an article by Saundra Willingham, a community organizer for Project Bridge and the former Sister Melanie who had been doused with water during SIS. In the article titled, "Why I Quit the Convent," she explained, "I left because I am black, they are white and 'ne'er the twain shall meet." 75 Willingham explained that, while she experienced no overt racism from within her community, the psychological cost of being black in an institutionally white environment had worn her down to the point of not being willing to make final

70. Project Bridge: An Assessment of a Program to Improve Black-White Relations in Cleveland, Ohio, 5-6.

71. Ibid., 5-8.

72. Ibid., 23.

73. Ibid., 24-26.

74. A Suburban Human Relations Foundation, Inc. 1969-1970, box 40, folder 1009, George Gund Foundation Records, Western Reserve Historical Society Archives, Cleveland, Ohio.

75. Saundra Willingham, "Why I Quit the Convent," Ebony (December 1968), 64. 
vows. She had little hope for large-scale reconciliation between the races but resolved to work for reconciliation on an individual scale. Willingham ended the article with: "Now, should the blood begin to flow, neither I nor anyone else will wonder who I am or where my loyalty is." ${ }^{76}$

Another sister, Joyce Williams, O.S.B., the only African-American member of her Minnesota-based community, joined Project Bridge in its second year. The assassination of Martin Luther King, Jr. had motivated her to leave her religious community's all-white high school and return to work on issues of race in Cleveland. Remaining a Benedictine, she lived with her family and worked at Petrarca Street. When speaking to suburban groups, she often spoke about the need for African-American autonomy: that white people should only assist African Americans when asked and, instead, work on changing their own racist attitudes. Moreover, she argued that black autonomy, such as black neighborhoods being protected by African-American police and black nuns running urban schools, had been rendered almost impossible by the white community which systematically excluded black candidates from positions of authority. Sister Joyce called for the white community to make restitution: "If you steal from me my good name, you have to give it back." 77 White restitution became a theme for Project Bridge's executive director as well. Speaking to a suburban congregation in Cleveland Heights, Thornton Webster argued that white people had brought Africans to America in chains. Because of this, it was incumbent upon the white population to make things right and work to advance the black community. ${ }^{78}$

This sense of militancy was not confined to new members of the Project Bridge staff. In January 1969, Sister Roberta Steinbacher, O.S.U., became part of Christians Who Care (CWC), a group of local Catholics organized to protest the Diocese of Cleveland's leadership. CWC was concerned about the diocese's perceived failure to implement the reforms of Vatican II, its support of an immoral war in Vietnam, and its perpetuation of racism by maintaining the status quo and catering to the wealthy. ${ }^{79}$ Led by two Catholic priests, Fathers Robert Begin and Bernard Meyer, CWC organized a Mass at St. John's Cathedral on Saturday, January 25, 1969. The cathedral parish typically celebrated a midnight mass so that second-shift downtown workers could fulfill their Sunday obligation before going home to bed. The CWC Mass began just before the regular midnight Mass. They believed that

76. Ibid., 74 .

77. "Nun Helps Her People in Ghetto," Cleveland Plain Dealer, April 26, 1969, 3-B.

78. "White Man's Burden is to Right Wrong to Negroes, Says Webster," Cleveland Plain Dealer, April 21, 1969, 11-A.

79. "Grievances Listed Against the Diocese," Cleveland Plain Dealer, January 27, 1969, 3 . 
once the Mass was underway, the cathedral staff would not disrupt it, and CWC could preach their message to the congregation. ${ }^{80}$ Instead, the cathedral staff called the police who arrested the priests as they distributed communion, disrupting the conclusion of the liturgy. ${ }^{81}$

The fallout within the Church from the protest was quick and dramatic. The Senate of Religious Women, a diocesan organization representing all forty-one women's communities in Cleveland, issued a statement deploring the use of the Mass to make a statement but recognizing the validity of the CWC's complaints. Similarly, the Greater Cleveland Catholic Interracial Council viewed the methodology of the protest as "questionable" but considered the reaction of the cathedral staff as even more scandalous. ${ }^{82}$ The Akron Area Catholic Interracial Council went further, supporting both the actions and agenda of CWC. ${ }^{83}$ The close ties that these organizations had with the diocese underscore the depth of these divisions.

The following Sunday's Cleveland Plain Dealer published a front-page story about dissent within mainstream American churches. Sister Roberta was not only interviewed for the article but featured in a photograph accompanying the article, and Saundra Willingham was quoted about the hypocrisy of the Catholic Church. ${ }^{84}$ The diocesan chancellor, Msgr. A. James Quinn, contacted the mother superior of Sister Roberta's Ursuline community in Kansas requesting that she be removed. Her superiors responded that she had done nothing wrong, but Sister Roberta sought other employment as a professor of urban studies at Cleveland State University. ${ }^{85}$ She was the last of the original staff to depart from Project Bridge.

The Project Bridge initiatives ended after two years when the Ford Foundation ceased its funding. ${ }^{86}$ Sister Roberta left the Ursulines for a faculty position at Cleveland State University. Thornton Webster went on to work for the Urban League of Greater Cleveland. ${ }^{87}$ In 1971, Sister Joyce Williams, O.S.B., became head of NCCIJ's Department of Education Serv-

80. Roberta Steinbacher, interview with author, April 3, 2019.

81. "Two Catholic Priests Face Trespass Charges," Cleveland Plain Dealer, January 27, $1969,1$.

82. "Summary of Statements," [Diocese of Cleveland] Catholic Universe Bulletin, January $31,1969,2$.

83. Ibid., 3.

84. Joseph Eszterhas, "Voices of Dissent Among the Clergy," Cleveland Plain Dealer, February 2, 1969, 1 .

85. Roberta Steinbacher, interview with author, April 3, 2019.

86. Marlene Stoiber, email to author, 2019.

87. “Thornton Webster, headed Project Bridge," Cleveland Plain Dealer, November 30, 2002, B7. 
ices in Chicago, replacing Sister Margaret Traxler, S.S.N.D., who became its executive director. ${ }^{88}$ The Urban Community School grew and prospered under the care of the Ursuline community in Cleveland. Today the school serves 585 students from diverse ethnic backgrounds, but its ties with the Diocese of Cleveland were severed in 2018 when the school decided to offer contraceptive services at a clinic on campus. ${ }^{89}$

Given the depth of segregation in Cleveland, Project Bridge's goals were difficult to achieve. Even today, Cleveland ranks last in neighborhood racial and ethnic diversity among major American cities. ${ }^{90}$ The thousands served by the Urban Community School suggested some potential for Project Bridge's combination of collegiality and subsidiarity to bring improvement, but many of their efforts proved ineffectual in addressing the significant problem of racism in Cleveland.

88. "Nun Here Gets Post in Chicago," Cleveland Plain Dealer, October 17, 1971, 48-D.

89. "Urban Community School and Cleveland Catholic Diocese sever ties due to contraception service planned at new MetroHealth clinic on campus," https://www.cleveland. $\mathrm{com} / \mathrm{metro} / 2018 / 12 /$ urban-community-school-severs-ties-with-cleveland-catholic-diocesedue-to-contraception-service-planned-at-new-metrohealth-clinic-on-campus.html.

90. Joe Cortright, "Identifying America's Most Diverse, Mixed Income Neighborhoods," http://cityobservatory.org/wp-content/uploads/2018/06/Identifying_ADMIN_ Report.pdf. 